\title{
Implementation of School-Based Management to Improve Education Quality at MAN 6 Pidie
}

\author{
Ida Rosyida*, Nurtanio Agus Purwanto \\ Education Management, Universitas Negeri Yogyakarta, Indonesia \\ Corresponding author. Email: idarosyida.2020@student.uny.ac.id
}

\begin{abstract}
This study aims to determine the implementation of school-based management to improve the quality of education in MAN 6 Pidie. This study is a case study which is focused on one phenomenon that is selected and understood in depth. The data was collected using observation, interview and documentary studies. The subjects were principals, vice principals, teachers and school committees. The data analysis technique was carried out through two activity, namely data presentation and data verification. The results of data analysis show that the implementation of schoolbased management by the principal at MAN Negeri 6 Pidie is excellent in accordance with the policies and planning. In addition, school principal is always responding and looking for solution to every problem in implementing schoolbased management (SBM).
\end{abstract}

Keywords: school-based management, quality of education

\section{INTRODUCTION}

To date, the problem that has not been overcome yet in education in Indonesia is the low quality of education. The low quality of education is not about unclear reason. This is due to the uneven distribution of government policies and efforts in in all educational units, ranging from provincial and city/district level to remote areas. Various efforts have been made to improve the quality of national education through various trainings, improvement of teacher competence, procurement of books and learning tools, improvement of educational facilities and infrastructure, and improving the quality of school management.

Since the education aspect is necessary to improve continuously, it needs an approach in improving the quality of education. It is hoped that empowerment, maturity and independence as well as the quality of the nation can be hrough education. Because education is one aspect of life that is functional for every human being and has a strategic position to educate the nation's life [1]. This approach is known as the concept of education management (SBM).
SBM basically gives schools freedom to carry out all activities related to the implementation of education to achieve educational goals effectively and efficiently. The application of school-based management is not only to bring the changes of management system in schools but also to influence policies and orientation to the community towards the implementation of education to improve the quality of education in schools.

SBM can be an alternative in improving the quality of education. SBM has been implemented in various countries. It basically consists of (1) decentralization principle, the delegation of authority to regions and schools to manage their education autonomously in the development of national education, (2) empowerment of educational resources including participation and empowerment of parents and the community in developing education, (3) the existence of a school committee board that monitors or organizes the provision of facilities and supervision in the management of education [2].

SBM is a policy set by the government in education that regulates and allows schools to make policies and manage their own households. SBM is a 
step that is considered the most effective and profitable to improve the quality of education in schools. Schools are given the freedom to make their own policies according to the needs and conditions of the school environment.

SBM aims to improve the quality of education, especially in the regions, because schools and the community do not need to wait for orders from the center but can develop an educational vision according to regional conditions and carry out the educational vision independently. The purpose of implementing SBM is to improve management efficiency as well as the quality and relevance of education in schools [3].

Management is a process that utilizes all existing resources effectively and efficiently to achieve a goal/target [4]. Management is an art, the art of managing all existing resources, both human resources and other resources, according to their respective functions so that they can effectively and efficiently achieve goals [5]. According to D. Andriany [6] management is a process of achieving organizational goals effectively and efficiently through planning, organizing, leadership, and monitoring organizational resources. Management is indispensable in modern social organizations characterized by scientific thinking and educational innovation. Overall, management is a process that regulates activities or behavior so that it has a good effect or art of directing others to achieve the main goals of an organization or business through the process of planning, organizing, managing, and controlling resources by means of effective and efficient.

SBM is a political approach that aims to redesign school management by giving power to school principals and increasing community participation in efforts to improve school performance, including teachers, students, school committees, parents and the community [7]. SBM changes the decision-making system by transferring the authority in decision-making and management to each stakeholder at the local level.

SBM aims to improve the effectiveness and efficiency of education. Effectiveness relates to appropriate and effective educational processes and outcomes as planned. The effectiveness of a school is surely known after releasing the results. On the other hand, to achieve good results, efforts are made to apply indicators or characteristics of effective schools [8]. By implementing SBM, it is hoped that every school, according to their respective conditions, can apply appropriate learning methods and media. As such, learning can run smoothly and effectively and is on target to improve the quality of education. Efficiency relates to the capital or costs incurred within limits that are not too large or small, but can fulfill all processes and maximum educational outcomes.

According to O. E. Muslihah [9], in order to run optimally, a strategy is needed in implementing SBM, including: (a) Grouping, schools can be grouped based on the ability of schools to manage their schools, thus it will be easier to know which schools require more attention, (b) Phased, the implementation of SBM is carried out through stages, starting from the short-term stage to the long-term stage, (c) Implementation, the trial implementation run first prior to the permanent implementation which requires binding regulations. Overall, the implementation of SBM is essentially choosing the best alternative for schools in developing their schools. SBM must carry out continuously to later result in an improvement of education.

Various supports from the components of education are needed to improve the quality of education as desired. At least, schools must have the following characteristics, namely: (a) Strong School Leadership, principals as leaders must able to utilize and carry out their functions to encourage and make decisions in improving school quality, (b) Effective Management of Education Personnel, education personnel, especially teachers, need to be managed properly, starting from their needs when teaching, participating in trainings to increase their teaching ability, evaluating teacher performance, and giving rewards for their services,(c) Schools Authority, schools have their own authority to improve themselves so that they can develop their respective abilities. (d) Schools Openness, openness means transparency in its management process, such as in the process of making a decision, in the use of school finances, and in evaluating the implementation of activities, (e) Good Communication, schools must establish good communication with the school's internal parties and external parties of the school. This well-established communication is intended so that all school later activities can be carried out properly because of the involvement of all existing components.

\section{METHODS}

This study uses a descriptive method with a qualitative approach, namely describing and analyzing the application of in improving the quality of education at MAN 6 Pidie. The research was conducted on June 13, 2021. Respondents were principals, vice principals of curriculum, teachers and administration staff. The criteria of the respondents are those who are able to answer / provide answers from researchers related to SBM at MAN 6 Pidie. The principal was 
involved because he was able to provide answers about the procedures for implementing SBM at MAN 6 Pidie. Vice Principals of curriculum, helped to complete the answers from the principal regarding SBM at MAN 6 Pidie. The teachers provided answers related to the results after the implementation of SBM in Man 6 Pidie. The staff helps finding data related to SBM.

According to Creswell [10] a qualitative approach is a research based on a methodology by investigating a social phenomenon and human problem. In this approach, the researcher creates a complex picture, examines words, reports detailed views of the respondents, and conducts studies in natural situations. Thus, it can be understood that descriptive research is a research method that seeks to describe the object or subject according to the aim. It also systematically describes the facts and characteristics of the object accurately. Furthermore, L. J. Moleong [11] also adds that qualitative research is research that intends to understand the phenomena of what is experienced by research subjects, such as behavior, perception, motivation, action, and others by way of description in the form of words and language, particularly in a natural context.

Researchers used data collection techniques through observation, interviews and documentation studies. he data that has been collected from the beginning of the study to the end of the study using data reduction techniques, data presentation and conclusions. Data reduction is simplifying, classifying, and removing unnecessary data in such a way that the data can produce meaningful information and make it easier to draw conclusions. The large amount of data and the complexity of the data require data analysis through the reduction stage. This reduction stage is carried out to select whether the data is relevant or not with the final goal.

\section{RESULTS AND DISCUSSION}

In discussing the results of this study, efforts will be made to interpret the results of research findings in the field that have been obtained. This is based on a perception that the main purpose of qualitative research is to gain meaning for the reality that occurs. Furthermore, a systematic discussion of the results of this research will be presented as follows:

The work program of the madrasah principal in realizing various educational programs at MAN 6 Pidie was clearly seen as viewed from the realization of various activities such as: (a) curriculum and teaching, (b) education staff, (c) students (student management), (d) finance and financing, (e) facilities and infrastructure, (f) school relations with the community, and $(\mathrm{g})$ special services. Not all madrasah principals understand and understand the purpose of leadership, the qualities, and the functions that must be carried out by leaders, especially in SBM.

The person who holds the position as a head of the madrasah is the education leader. S. Aminah, A [12] stated that the duties and responsibilities of the madrasah head can be classified into two area: (a) the duties in administrative field, and (b) the duties in supervisory field. The duties of the madrasah principal in administration including managing teaching, staffing, students, school buildings and grounds, school finances, school and community relations. The tasks in supervision include providing guidance, assistance, supervision and assessment on problems related to the technical implementation and development of teaching education improve teaching education programs and activities to create teaching and learning situations.

The way principal works and views his role is influenced by his personality, professional preparation and experience, and the decisions made by the school regarding the role of the madrasah principal in teaching. Education services in the office for school administrators can clarify expectations for the role of the madrasah principal.

According to S. Rizal [13], the head of the madrasah has 11 kinds of roles, namely executor, planner, an expert, supervor for the relationship between members, represtation of the group, a rewarder, a referee, responsibility holder, a creator and a father.

\subsection{Strategy for the Implementation SBM at MAN 6 Pidie}

The strategy for implementing SBMt at MAN 6 Pidie includes the following aspects: (a) stages of socialization, (b) formulation of the school's vision, mission and goals, (c) identification of the school's real challenges, (d) goals/objectives situational, (e) functions that need to be involved to achieve the target, (f) SWOT analysis, (g) alternative problem solving steps, (h) preparation of quality improvement work plans and programs, (i) program implementation and evaluation, and (j) formulation of new quality objectives.

There are at least four important aspects of SBM implementation that must be taken into consideration, quality and relevance, fairness, effectiveness and efficiency, and accountability. SBM aims to achieve the highest quality and relevance of education, with the benchmark for assessing results (outputs and outcomes) not on the methodology or process. In order for schools 
to take advantage of the benefits offered by SBM, it is necessary to develop a professional development center, which functions as a provider of training services for education personnel for SBM[14].

In iaddition, it is important to note that schools and communities need to be involved in the SBM process as early as possible. They need not just wait, but involve themselves in discussions about SBM and take the initiative to organize related aspects. Basically, changing the central-based management approach to SBM is not a very easy matter, but it is a process that takes place continuously and involves all elements responsible for the implementation of school education.

\subsection{Obstacles Faced by Madrasah Principals in Implementing SBM at MAN 6 Pidie}

The obstacles faced by madrasah principals in implementing SBM at MAN 6 Pidie can be identified through the indicators of (a) school independence, (b) participatory decision making, and (c) management transparency. Further, they are described as follows:

\subsubsection{Obstacles of SBM in school independence}

In order to show its independence according to the essence of school autonomy, schools try to meet their needs together with school committees without relying on government support. Schools raise funds to get their own funds (self-funding) so that the education process at schools can run smoothly. Furthermore, schools try to manage their own funds effectively and efficiently. There is a priority scale in carrying out school goals that have been determined. In carrying out various school activities to implement education and improve quality, schools try to carry out their own (self-employment) without asking for instructions.

\subsubsection{Obstacles of SBM in Participatory Decision}

\section{Making}

The principal as the central figure in the school has a very important role that will determine the atmosphere in the school, and the regulations that will be applied through the right decision-making process. In making decisions, the principal must be wise before the decision is socialized to the school community, because what is conveyed by the head of the madrasah is always heard and will then be implemented by the school community.

The role of the madrasah principal is very large which will have a huge impact on life at school. The role of the head of the madrasa include as an administrator, educator, leader and motivator of his subordinates. From this context, the head of the madrasah has a very big influence in school life, because the head of the madrasah is considered a leader who provides a good example.

Overall, the leadership style of madrasah principals in decision-making socialization activities is very useful in providing thoughts on how to deal with various styles of decision-making. Good school management is capable of producing quality school decisions, both quantitatively and qualitatively [12]. There is no better school management, except which can achieve positive, rational, and objective changes for school organizations.

Therefore, the skills of the madrasah principal as a manager in decision-making activities are a demand for competencies that must be possessed and a demand for quality management to encourage the development of organizational and management programs. Thus, the skills needed by managers in decision-making activities are: (a) cognitive skills, (b) data collection and processing skills, (c) communication skills, (d) influencing skills, and (e) managerial skills. It is clear that madrasah principals develop school excellence starting from planning to evaluation, so that schools can realize school excellence. Next, they can adapt to the development of science, technology according to their needs of developing the quality of human resources.

\subsubsection{Obstacles to SBM in Transparency Management}

The transparency of madrasah principals in the implementation of SBM can be seen from the openness in formulating and deciding a policy that involves school elements. These transparent activities include: (a) identifying real challenges faced by schools, (b) identifying the readiness level of functions and their factors in a SWOT analysis, (c) determining alternative problem-solving steps, preparing plans and work programs for quality improvement in shorts term (one year ahead), (d) implementing the plenary meeting of the school committee at the beginning of the new school year, attended by all parents of students, committee members, community leaders and relevant government officials, with the main agenda of ratifying the RAPBS, (e) conducting continuous coordination, (f) creating inventory of activities types and activity implementers, (g) placing personnel in accordance with the assigned type and workload, (h) discussing the allocation of funds for each activity, (i) providing a place/board of information regarding various school matters, (j) accepting criticism and suggestions from the public on school performance.

\section{CONCLUSION}

It can be concluded that the madrasa principal's work program in educational activities at MAN 6 Pidie has 
been functioned properly and correctly. In education, staff management, financial management and financial roles have not been carried out optimally.

The strategy for implementing school-based imanagement at MAN 6 Pidie is carried out through: (a) the socialization stage, (b) the formulation of the school's vision, mission and goals, (c) nvolvement of a number of educational resources for the achievement of the school program, (d) the execution of a SWOT analysis on education programs that have been implemented, (e) the preparation of plans and work programs for quality improvement, and (f) the evaluation of program implementation. Obstacles faced by madrasah principals in implementing SBM include school independence and budget management which have not been implemented in a transparent and accountable manner.

\section{ACKNOWLEDGMENTS}

The authors would like to thank the Principal of MAN 6 Pidie, and to all stakeholders who have helped the research. I would also like to thank all those who have been involved and helped in the making of this article.

\section{REFERENCES}

[1] S. Sunanto, "Implementasi Manajemen Berbasis Sekolah Dalam Peningkatan Mutu Pendidikan Pada SMP Negeri 19 Percontohan Banda Aceh," Intelektualita, vol. 3, no. 1, 2015.

[2] A. S. Bugis, R. Body, and T. Andayono, "Persepsi Guru terhadap Pelaksanaan Manajemen Berbasis Sekolah (MBS) di Smk Negeri 4 Pariaman," CIVED (Journal Civ. Eng. Vocat. Educ., vol. 5, no. 3, 2018.

[3] S. Muhammad and M. Rahman, "Implementasi Manajemen Berbasis Sekolah Untuk Meningkatkan Mutu Sekolah Dasar Islam Insan Kamil Bacan Kabupaten Halmahera Selatan," Edukasi, vol. 15, no. 1, 2017.

[4] Nurkolis, Manajemen berbasis sekolah: Teori, model, dan aplikasi. Gramedia Widiasarana Indonesia, 2003.

[5] S. P. Malayu, "Hasibuan, Manajemen dasar, pengertian dan masalah," Jakarta Bumi Aksara, 2009.

[6] D. Andriany, "School Student Management Plus: Concepts, Strategies, and Implementation," Jakarta: Mitra Wacana Media, 2019.

[7] A. Kurniawan, "Apakah Total Quality Management Meningkatkan Mutu Sekolah
Menengah Atas Di Kota Cirebon?," AL-TANZIM J. Manaj. Pendidik. Islam, vol. 4, no. 2, pp. 197208, 2020.

[8] M. Ridha, "Manajemen Berbasis Sekolah Berorientasi Pelayanan Publik: Teori dan Implementasinya." Zahir Publishing, 2018.

[9] O. E. Muslihah, "Understanding the Relationship between School-Based Management, Emotional Intelligence and Performance of Religious Upper Secondary School Principals in Banten Province.," High. Educ. Stud., vol. 5, no. 3, pp. 11-23, 2015.

[10] P. D. Sugiyono, "Metode penelitian pendidikan," Pendekatan kuantitatif, 2010.

[11] L. J. Moleong, "Metodologi penelitian kualitatif (Cet. Ke-30.)," Bandung: Remaja Rosdakarya, 2012.

[12] S. Aminah, A. R. Murniati, and N. Usman, "Implementasi Manajemen Berbasis Sekolah dalam meningkatkan mutu pendidikan pada MTsN kota Lhokseumawe," J. Adm. Pendidik. Progr. Pascasarj. Unsyiah, vol. 3, no. 2, 2015.

[13] S. Rizal, “Analisis Manajemen Berbasis Sekolah (Mbs) Dalam Peningkatan Pembelajaran Pendidikan Agama Islam (Studi Kasus Di Smp AlWashliyah 8 Univa Medan)," Wahana Inov. Vol. 3 No. 2 Issn 2089, vol. 8592, p. 295, 2014.

[14] Y. Mulyadi, I. C. Hermawan, and T. Sulaeman, "Manajemen Berbasis Sekolah Dalam Peningkatan Kualitas Pendidikan,” J. Pendidik. Polit. Huk. Dan Kewarganegaraan, vol. 11, no. 1, 2021. 